\title{
Sustainable Remediation of Contaminated Soil Using Biosurfactants
}

\author{
Catherine N. Mulligan* \\ Concordia Institute of Water, Energy and Sustainable Systems, Concordia University, Montreal, QC, Canada
}

Selection of the most appropriate remediation technology must coincide with the environmental characteristics of the site. The risk to human health and the environment at the site must be reduced, and not be transferred to another site. Biosurfactants have the potential as remediation agents due to their biodegradability, low toxicity, and effectiveness. Selection of biosurfactants should be based on pollutant characteristics and properties, treatment capacity, costs, regulatory requirements, and time constraints. Moreover, understanding of the mechanisms of interaction between biosurfactants and contaminants can assist in selection of the appropriate biosurfactants for sustainable remediation. Enhanced sustainability of the remediation process by biosurfactants can be achieved through the use of renewable or waste substrates, in situ production

OPEN ACCESS

Edited by:

Rudolf Hausmann,

University of Hohenheim, Germany

Reviewed by:

Eric D. van Hullebusch,

Université de Paris, France

Margarida M. Fernandes,

University of Minho, Portugal

*Correspondence:

Catherine N. Mulligan

catherine.mulligan@concordia.ca;

mulligan@civil.concordia.ca

Specialty section:

This article was submitted to Industrial Biotechnology,

a section of the journal

Frontiers in Bioengineering and

Biotechnology

Received: 30 November 2020

Accepted: 23 February 2021

Published: 15 March 2021

Citation:

Mulligan CN (2021) Sustainable Remediation of Contaminated Soil

Using Biosurfactants.

Front. Bioeng. Biotechnol. 9:635196.

doi: 10.3389/fbioe.2021.635196 of biosurfactants, and greener production and recovery processes for biosurfactants. Future research needs are identified.

Keywords: sustainable remediation, biosurfactants, indicators, organic contaminants, metal, metalloid

\section{INTRODUCTION}

Cost-effective solutions that require less resource are significant factors in determining the treatment of contaminated sites. Both in situ and ex situ treatment approaches are available, but the most appropriate selection must be sustainable and based on the site characteristics (Mulligan, 2019). The risk to human health and the environment must be reduced in all management steps. For example, for contaminated sediments, the risks of dredging, disposal, and/or potential beneficial reuse of the sediments must be determined. To work toward sustainability, indicators must be identified and quantified. During remediation, waste generation and landfill deposition must be minimized, natural resources conserved, and benthic habitats and wetlands protected (Yong et al., 2014). Landfills will continue to be filled with contaminated sediments and soil, and biodiversity in the environment will be reduced unless changes are made. Integrated innovative management practices need to be developed to ensure that the remediation practices are performed sustainably.

A potential solution for the pump and treatment method could involve the use of biobased products such as biological surfactants instead of petroleum-based ones. Mulligan (2014b) has shown that biodegradable, non-toxic products called biosurfactants (e.g., rhamnolipids and sophorolipids) can be produced from waste materials and can be employed for soil flushing or washing for metal and organic contaminants or for enhanced biodegradation of organic pollutants. Biosurfactant applications for remediation of contaminated soil and water have potential based on low toxicity, high biodegradability, unlimited applicability, and relatively low production cost for sustainable remediation and critical micelle concentration (CMC) and high effectiveness in enhancing biodegradation and affinity for metals. Studies showed that for effective application of 
biosurfactants, they should be selected based on pollutant characteristics and properties, treatment capacity, costs, regulatory requirements, and time constraints. Moreover, understanding of the mechanisms of interaction between biosurfactants and contaminants can assist in selection of the appropriate biosurfactants for sustainable remediation. Enhanced sustainability of the remediation process by biosurfactants can be achieved through the use of renewable or waste substrates, in situ production of biosurfactants, and greener production processes of biosurfactants. Most research has involved rhamnolipids. Other biosurfactants and process scale-up need further investigation. Therefore, in this paper, the application of biosurfactants for remediation as a potentially more sustainable option and future research needs are discussed.

\section{ENVIRONMENTAL APPLICATIONS OF BIOSURFACTANTS}

\section{Rhamnolipids}

Rhamnolipids are anionic due to their carboxylic moiety (Tan et al., 1994; Herman et al., 1995; Ochoa-Loza, 1998). Therefore, metals with positive charge can be removed by rhamnolipids added to soil and sediment as reviewed by Mulligan (2014b). Juwarkar et al. (2007) showed the rhamnolipid decreased toxicity and enhanced microbial activity (Azotobacter and Rhizobium) which showed improved soil quality, but cost effectiveness was not evaluated.

Rhamnolipid was evaluated for its ability to reduce soil ecotoxicology of an aged, contaminated soil (Slizovsky et al., 2011). By removing 39, 56, 68, and $43 \%$ of $\mathrm{Zn}, \mathrm{Cu}, \mathrm{Pb}$, and $\mathrm{Cd}$, the toxicity reduction of the treated soil was demonstrated by the increase in biomass levels and survival of two species of worms (Eisenia fetida and Lumbricus terrestris).

Although most studies have focused on cation removal, it has also been found that anions (chromium and arsenic) can also be removed. Massara et al. (2007) demonstrated the removal of $\mathrm{Cr}$ (III) by rhamnolipids from kaolinite and the reduction of $\mathrm{Cr}(\mathrm{VI})$ to $\mathrm{Cr}$ (III) within 24 days. Further research indicated hexavalent chromium extraction and reduction by rhamnolipids from contaminated water and soil (Ara and Mulligan, 2015). Mining residues were also studied for removal of the As(V) form, at high $\mathrm{pH}$ by rhamnolipids (Wang and Mulligan, 2009b). Cu, Zn, and $\mathrm{Pb}$ removal is also positively correlated with that of arsenic.

Another way to add a surfactant to contaminated soil is in the form of a foam. It could be potentially more efficient than a biosurfactant solution. A $0.5 \%$ rhamnolipid foam solution was evaluated for cadmium and nickel removal from a contaminated sandy soil (Mulligan and Wang, 2004) and for the treatment of fresh water sediments co-contaminated with polycyclic aromatic hydrocarbons (PAHs), $\mathrm{Pb}, \mathrm{Zn}$, and $\mathrm{Ni}$ (Alavi and Mulligan, 2011).

Congiu and Ortega-Calvo (2014) studied the influence of the rhamnolipid biosurfactant on PAH biodegradation. Two mechanisms for the biosurfactant use were identified: (a) micellar solubilization, which improved the $\mathrm{PAH}$ availability to microbial cells for biodegradation and (b) rhamnolipid partitioning into soil organic matter that increased the $\mathrm{PAH}$ desorption rate from the soil.

Mulligan and Roshtkhari (2016) showed that rhamnolipid and microbial cultures isolated from weathered oil could enhance flocculation of the oil sands tailings by a factor of 2.70. The mechanism of flocculation appeared to involve a hydrophobicity increase of the particles, followed by adsorption of the biosurfactants and other organic compounds to bridge between particles. The sedimentation of the tailings will allow reduction in the volume of the ponds.

A rhamnolipid-producing strain of Lysinibacillus sphaericus strain was studied by Gaur et al. (2019). The solubilities of various pesticides were enhanced including $\beta$ endo-sulfan and $\Upsilon$ hexachlorocyclohexane. The biosurfactant also had antimicrobial activities against six strains of pathogenic bacteria (Aeromonas hydrophilia MTCC 1143, Bacillus subtilis MTCC 441, Escherichia coli MTCC 723, Klebsiella pneumonia MTCC 109, Pseudomonas aeruginosa MTCC 424, and Vibrio cholera MTCC 3904).

\section{Surfactin}

Surfactin is a lipopeptide produced by B. subtilis consisting of seven amino acids in a 14-carbon compound (Kakinuma et al., 1969). Surface tensions decreased to $27 \mathrm{mN} / \mathrm{m}$ with low surfactin concentrations $(0.005 \%)$. Production costs are high due to low yields and expensive substrates. Various food by-products and wastes have been used as substrates including whey, sugar cane molasses, maize water, cashew apple juice, olive oil, and potato processing effluents (Mulligan, 2014a).

The two negative charges on the glutamate and the aspartate portions of surfactin enable the binding of various metals (Thimon et al., 1992). Subsequently, heavy metals desorption by surfactin from contaminated soil and sediments was demonstrated by batch washing experiments (Mulligan et al., 1999a). The mechanism of surfactin enhanced metal extraction was attachment to the soil interface and metal complexation by the biosurfactant, and subsequent detachment of the metal/micelle complex.

Other studies by Singh and Cameotra (2013) indicated that surfactin and a fungicide were produced by the strain $B$. subtilis A21. The lipopeptide was effective for the removal of both petroleum hydrocarbons (65\%) and metals such as Cd, Co, Zn, $\mathrm{Pb}, \mathrm{Ni}$, and $\mathrm{Cu}(26-44 \%)$ under various conditions. Sorption on the soil of the biosurfactant decreased the efficiency by about $50 \%$. Mustard seed germination after the soil washing process, was improved, indicating the environmentally friendly nature of the biosurfactant.

A study with two biosurfactants, surfactin and saponin, was performed to compare foam fractionation and soil washing for the removal of potential toxic metals $(\mathrm{Cu}, \mathrm{Zn}$, and $\mathrm{Pb}$ ) from an industrial contaminated soil (Maity et al., 2013). Saponin and foam fractionation were more effective than surfactin and soil flushing. $\mathrm{Pb}$ was extracted more than $\mathrm{Cu}$ and $\mathrm{Zn}$.

Das and Kumar (2018) studied an indigenous biosurfactantproducing Bacillus licheniformis strain for remediation of petroleum-contaminated soil. The biosurfactant was identified as a lipopeptide. Potato peel powder (an agroindustrial waste), in addition to the petroleum, was used to produce the biosurfactant. 
Experiments were carried out as a bioslurry. The toxicity reduction of the contaminated soil was determined through the earthworm toxicity test and the seed germination inhibition assay. The bioslurry treatment (500 g per $1 \mathrm{~L}$ water) with the microbial strain with and without potato peel powder successfully reduced the toxicity of the soil.

Isolation of a lipopeptide-producing strain of $B$. subtilis from a creosote-contaminated soil (Bezza and Chirwa, 2015) showed that the lipopeptide could recover $85 \%$ of the motor oil from sand. In biodegradation experiments, the lipopeptide enhanced the degradation of the oil by twofold. The lipopeptide was stable from $\mathrm{pH} 5$ to 12,25 to $125^{\circ} \mathrm{C}$, and salinity of 5 to $20 \%$. It also showed emulsification properties against of hexane and cyclohexane. Therefore, the lipopeptide has potential for enhanced oil recovery and petroleum-contaminated soil remediation.

Ashish (2018) studied the use of Candida tropicalis MTCC230 for its ability to enhance microbial enhanced oil recovery (MEOR) by a lipopeptide biosurfactant. The surface tension of water could be reduced to $32 \mathrm{mN} / \mathrm{m}$. The CMC was $32.5 \mathrm{mg} / \mathrm{L}$. The lipopeptide was stable under wide $\mathrm{pH}(2-12)$, temperature $\left(30-90^{\circ} \mathrm{C}\right)$, and salinity $(2-10 \%)$ ranges. Soil washing tests showed the ability to remove hydrocarbon contaminants from both water and soil. The suitability for MEOR was also indicated.

Felix et al. (2019) studied the use of cashew apple juice as a substrate for biosurfactant production for remediation of oilcontaminated soil. The biosurfactant lipopeptide reduced the surface tension of water and the interfacial tension with oil to 31.8 and $27.2 \mathrm{mN} / \mathrm{m}$, respectively, with a CMC of $12.5 \mathrm{mg} / \mathrm{L}$. The toxicity against lettuce and a microcrustacean was very low with a LC50 of $612 \mu \mathrm{g} / \mathrm{mL}$. It was stable against $\mathrm{pH}$, salinity, and temperature changes and was effective for remediation of oil-contaminated soil.

\section{Sophorolipids}

The yeast Candida bombicola (formerly known as Torulopsis bombicola) produces a sophorolipid biosurfactant (Cooper and Paddock, 1984). The sophorolipid is produced in high yields which make it a potentially economic biosurfactant. Crude sophorolipids could potentially enhance metal removal from soils and sediments (Mulligan et al., 1999b, 2001).

Arab and Mulligan (2018, 2020) evaluated the use of sophorolipids for washing mining tailings. Increasing the temperature from 15 to $23^{\circ} \mathrm{C}$ increased removal of arsenic, copper, and iron, indicating its potential for remediation of mine tailings. In another study, Da Rocha et al. (2019) determined that the biosurfactant of $C$. tropicalis was much more effective for $\mathrm{Zn}$ and $\mathrm{Cu}$ removal than $\mathrm{Pb}$. An economic analysis suggested the potential for industrial remediation by the biosurfactant. Ashish (2018) examined the application of a C. tropicalis biosurfactantproducing strain for remediation of motor oil contaminated sand.

Dispersion of biodiesel, diesel, and light crude-oil by sophorolipids was studied (Saborimanesh and Mulligan, 2018). Decreasing the surface and interfacial tension and micelle encapsulation of oil was determined as the main mechanism for the enhanced dispersion by the biosurfactant. Further study examined the biodegradability of these petroleum products by indigenous oil degrading bacteria with and without biodispersant addition (Saborimanesh and Mulligan, 2015). Characterization by $16 \mathrm{~S}$ rRNA pyrosequencing indicated that Firmicute was the dominant phylum in the biodegradation of the biodiesel and diesel, whereas Actinobacteria in the diesel and Proteobacteria and Actinobacteria in the light crude oil. Addition of the sophorolipid enhanced the dispersion of the biodegradation of the hydrocarbons.

\section{Saponin and Other Biosurfactants}

Plant-based non-ionic saponin is another biosurfactant that has been studied for removal of heavy metals from various soil types (Hong et al., 2002). Maximal cadmium and zinc removal from regesol was $90-100 \%$, respectively. Unlike the previously discussed biosurfactants, saponins can be extracted from various plant parts such as the seeds, fruits, roots, and stems and are often classified as triterpenoids and steroid saponins. This wide distribution could make mass production easier and less costly (Kobayashi et al., 2012). For zinc, Mulligan et al. (2001) also found that saponin behaved in a similar manner to surfactin and rhamnolipid tests. Zeng et al. (2005) indicated that saponins can assist microorganisms for remediation by enhancing mass transfer and modifying cell hydrophobicity to enhance biodegradation. The surface tension of compounds like PAHs could be reduced.

Song et al. (2008) found that saponin was effective for removing phenanthrene and cadmium, from soil (87.7 and $76.2 \%$, respectively). The mechanism for remediation of the organic contaminant, phenanthrene, was by solubilization and for cadmium, it was complexation with the carboxylic groups of saponin. At pH 6.5, saponin $(2000 \mathrm{mg} / \mathrm{L})$ was able to desorb $83 \%$ of the copper and $85 \%$ of the nickel from kaolin (Chen et al., 2008). Comparison to other agents showed the following: ethylenediaminetetraacetic acid (EDTA) > saponin $>$ sodium dodecyl sulfate (SDS). The mechanism was adsorption of the surfactant, formation of metal ion pairs, and then desorption of the metal. More recently, Kobayashi et al. (2012) and Zhou et al. (2013) have shown that PAHs of three to five rings could be solubilized by saponin, and Cao et al. (2013) showed the desorption of $\mathrm{PCB}$ with $\mathrm{Cu}$ and $\mathrm{Pb}$ by saponin with ethylenediamine-N,N'-disuccinic acid (EDDS), while Ye et al. (2015) performed washing tests with a peanut oil-water solvent system with saponin for removal of polybrominated diphenyl ethers (PBDEs), polychlorinated biphenyls (PCBs), and PAHs and heavy metals from soil in conjunction with phytoremediation.

Liu et al. (2017) summarized the requirements for sustainable remediation with saponins. These included:

1. Model development for prediction of the ability of saponins to remove contaminants by biodegradation, flushing, or washing under a variety of conditions.

2. Improvement of purification and screening techniques for saponins.

3. Development of new applications regarding stabilization of nanoparticles for remediation. 
TABLE 1 | Selected biodegradation studies and soil washing/flushing studies involving biosurfactants.

\begin{tabular}{lllll}
\hline & & & (A) Biodegradation studies & \\
\hline Biosurfactant & Medium & Microorganism & Contaminant & References \\
\hline Crude biosurfactant & Soil & Bacillus subtilis ICA 56 & Hydrocarbons and heavy metals & Lima de Franca et al. (2015) \\
Rhamnolipid & Soil & Luteibacter sp. & Petroleum and heavy metals & Zhang et al. (2011) \\
Rhamnolipid & Soil & P. chrysosporium & PAHs & Wang et al. (2014) \\
Rhamnolipid & Sand & Indigenous microorganisms & PAHs, n-alkanes & Nikolopoulaou et al. (2013) \\
Rhamnolipid & Soil & P. aeruginosa DSVP20 & Eicosane, fluoranthene, pristane & Sharma et al. (2015) \\
Rhamnolipid & Soil & Indigenous microorganisms & Diesel oil & Whang et al. (2008) \\
Rhamnolipid & Soil & P. putida ATCC 17484 & Phenanthrene & Gottfried et al. (2010) \\
Rhamnolipid & Soil & Pyrene degrading bacteria & Pyrene & Jorfi et al. (2014) \\
Rhamnolipid & Soil & Indigenous microorganisms & Chloropyrifos & Singh et al. (2016) \\
Rhamnolipid & Sediment & Indigenous microorganisms & Triclosan & Qian et al. (2016) \\
Rhamnolipid & Soil & P. chrysosporium & Organochlorine pesticides & Wang et al. (2014) \\
Rhamnolipid & Soil & Pseudomonas aeruginosa A11 & Hg, Ni & Singh and Cameotra (2013) \\
Lipopeptide & Soil & Staphylococcus sp. & High salinity crude oil & Hentati et al. (2021) \\
Saponin & Soil & Burkholderia cepacia RPH1 & Phenanthrene & Choi et al. (2009) \\
Biosurfactants & Soil & Enterobacteriae, Pseudomonas, and other isolates & PAHs & Cazals et al. (2020) \\
\end{tabular}

(B) Soil washing/flushing studies

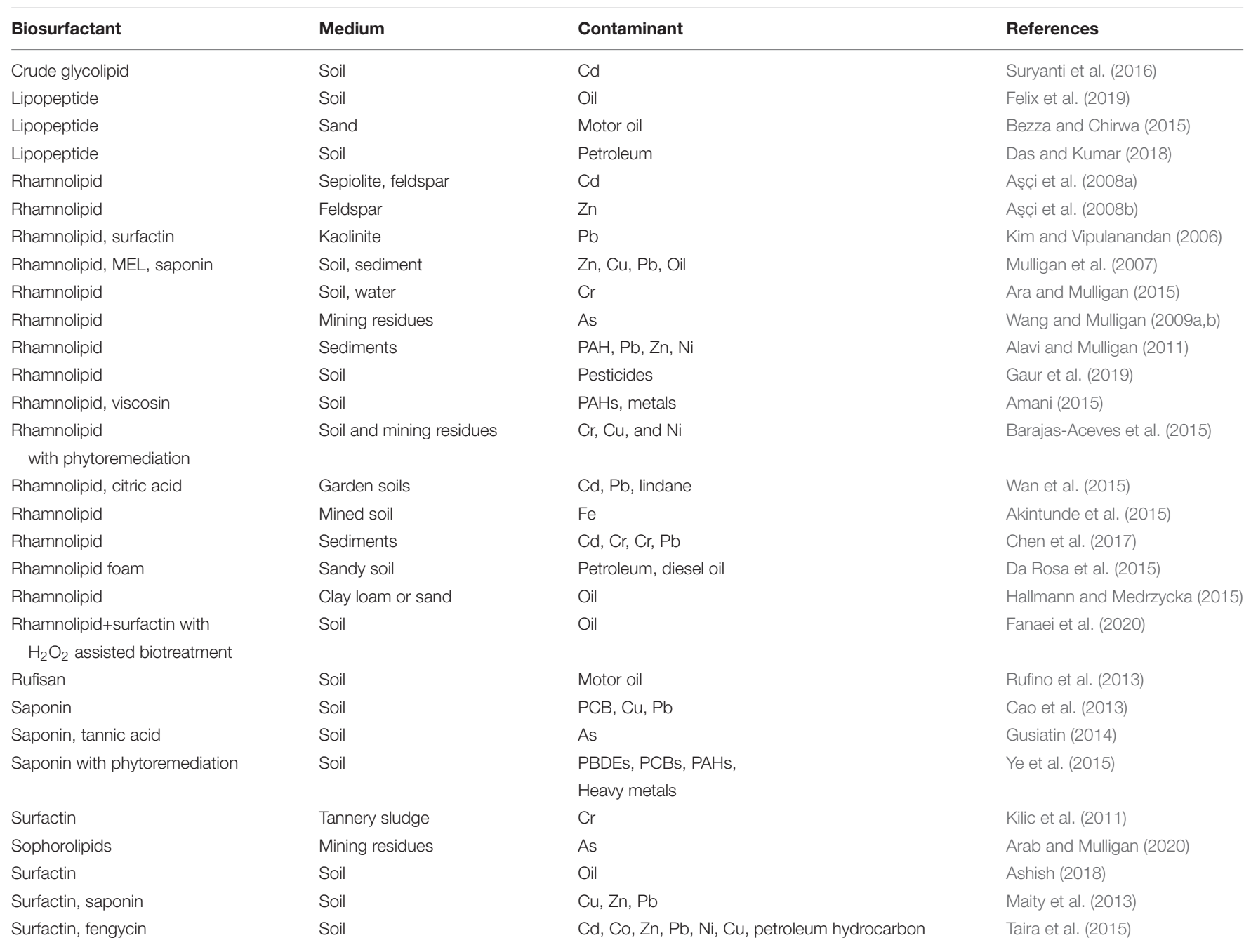


A study by Rufino et al. (2013) showed that a yeast synthesized Rufisan biosurfactant which decreased the surface tension to $25.3 \mathrm{mN} / \mathrm{m}$. Between 30 and $98 \%$ of the motor oil was removed from soil, respectively, by both the crude Rufisan biosurfactant and the purified biosurfactant at its CMC. The soil type and biosurfactant concentration did not affect the oil removal rate. Thus, the main mechanism of oil removal was likely oil displacement.

Resende et al. (2017) isolated a bacterial strain from seawater. The surface tension was reduced to $29 \mathrm{mN} / \mathrm{m}$, and a maximum concentration of $3.6 \mathrm{~g} / \mathrm{L}$ was produced. The strain was also very stable. A frying oil showed the best results for biosurfactant production. Motor oil could be removed by up to $90 \%$ from soil. Therefore, it has potential for future remediation.

Suryanti et al. (2016) examined the production of a glycolipid biosurfactant by Rhodococcus rhodochrous for remediation of cadmium. The biosurfactant had a CMC of $896 \mathrm{mg} / \mathrm{L}$ and could stabilize an emulsion up to 12 days. Both partially purified and crude biosurfactants were evaluated. The crude form could adsorb Cd slightly better than the purified form; thus, this form would be more economic.

\section{DISCUSSION AND FUTURE RESEARCH DIRECTIONS}

The concept of industrial ecology is to protect the environment and conserve resources (Mulligan, 2019). Principles include use of renewable resources and conservation of materials for industrial activities, efficient industrial production processes including reduction, recovery, recycling, and reuse of waste, and effective management of wastes and emissions. Biosurfactant production and their application for soil remediation should be viewed in this light.

Various applications of biosurfactants for treatment of contaminated soils, sediment, and waste (e.g., tannery sludge and mining wastes) have been discussed. Some of the applications of biosurfactants for biodegradation for mixed contaminants are

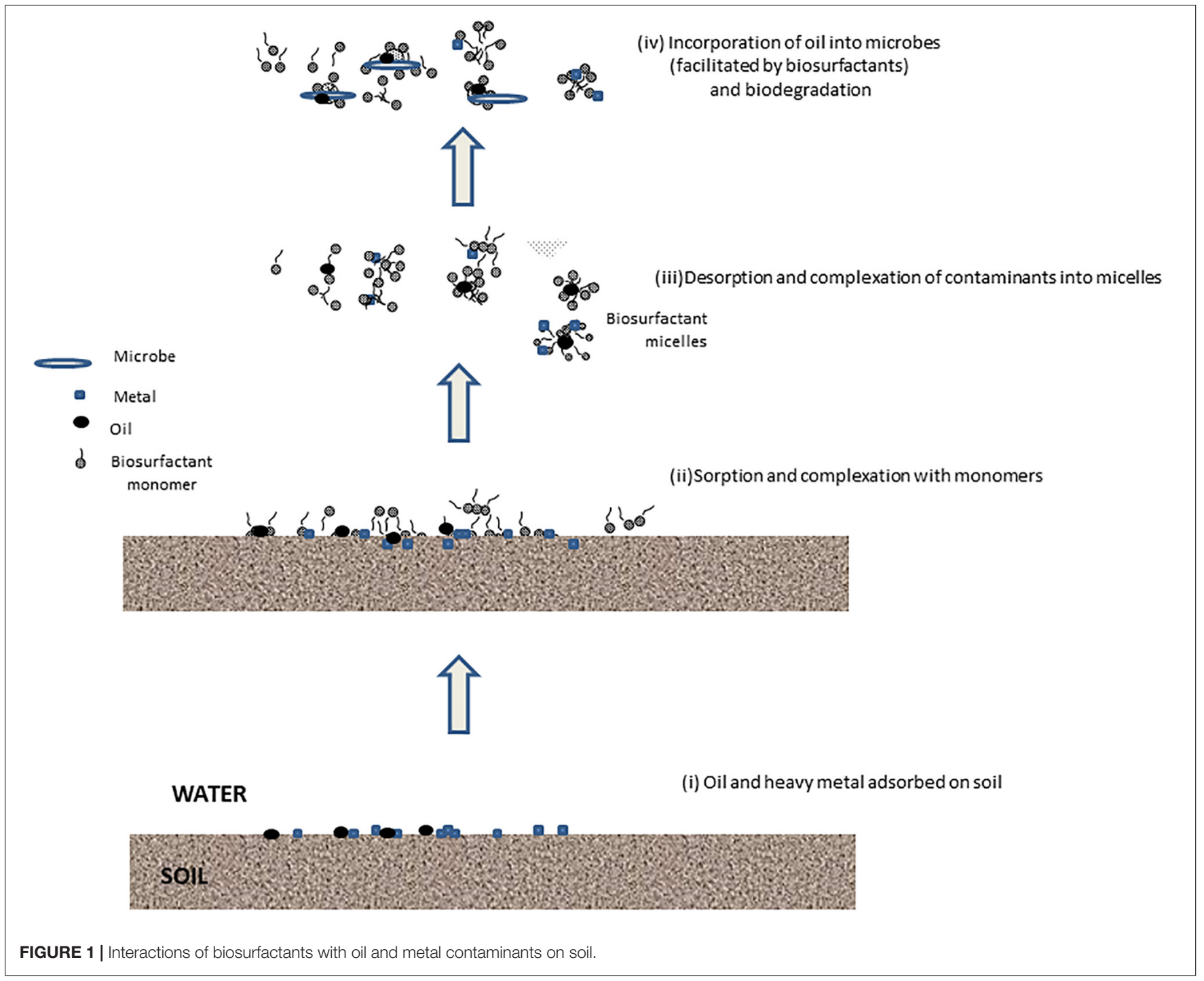


shown in Table 1A and for washing or flushing in Table 1B. By solubilization and emulsification of the contaminants, biosurfactants can enhance biodegradation of contaminants. Since the biosurfactants are biodegradable, biosurfactants remaining after treatment will not contribute toxicity to the treated soil. More research of more complex situations is needed, particularly regarding mixed organic and inorganic contamination. The mechanism of removal by the biosurfactants of oil and metal contamination is shown in Figure 1.

The high cost of producing the biosurfactants has limited full scale applications. This is due to low yields, rates of production, and recoveries (Descaro et al., 2017). The chemical properties of different congeners are also difficult to control. Genetic manipulation is underway to produce congeners appropriate for specific applications. Crude preparations and inexpensive or waste substrates can be employed (Mulligan and Gibbs, 1993). Waste materials as substrates will also improve the sustainability of the production process through cost reduction and waste reduction. As indicated by Marchant (2019), a full life cycle analysis (LCA) is necessary to identify where costs such as energy requirements during the fermentation process can be reduced. For example, Mulligan and Gibbs (1993) indicated that low-cost raw materials, increasing yield and production rates, optimization of the fermentor operation, reduction of product recovery costs, and matching the appropriate biosurfactant grade with the application will optimize the process costs such as employing crude instead of purified biosurfactants for environmental applications.

Biosurfactants thus can be produced externally and added to soil in situ or through soil washing. Subsequent recovery of the biosurfactants for reuse can enhance process sustainability. Liu et al. (2018) reviewed the substrates used by rhamnolipid producers. These include a variety of soluble sugars (glucose and glycerol), hydrocarbons (crude oil and diesel), and vegetable oils (e.g., coconut, palm, olive, etc.). For more sustainable production, waste substrates have been studied to reduce disposal issues and costs but can be inconsistent in quality. Some of these include water-mixable waste, molasses, whey milk or distillery waste peels of various fruits and vegetables, wastes from coffee and tea, whey, and waste cooking oils (Mulligan, 2014b).

Another approach is to biostimulate the microorganisms to produce the biosurfactants in situ. This reduces soil transportation costs and reduces risk of contaminant exposure and degrades the organic contaminants. Enhanced sustainability of the remediation process by biosurfactants can be achieved through the use of renewable or waste substrates, in situ

\section{REFERENCES}

Akintunde, T. A., Abioye, O. P., Oyeleke, S. B., Boboye, B. E., and Ijah, U. J. J. (2015). Remediation of iron using rhamnolipid-surfactant produced by Pseudomonas aeruginosa. Res. J. Environ. Sci. 9, 169-177. doi: 10.3923/rjes. 2015.169.177

Alavi, A., and Mulligan, C. N. (2011). "Remediation of a heavy metal and PAH-contaminated sediment by a rhamnolipid foam," in Proceedings of the Geo-Environmental Engineering 2011, Takamatsu, Japan, May 21-22, 2011. Takamatsu. production of biosurfactants, and greener production processes of biosurfactants. In situ biosurfactant production could be sustainable and cost effective due to the lower labor, material, energy, and transport requirements. Various biosurfactantproducing strains of Bacillus and Pseudomonas have been determined at hydrocarbon-contaminated sites (Jennings and Tanner, 2000) and thus stimulating in situ production could be strategic (Jalali and Mulligan, 2008). The role of in situ biosurfactant production could also enhance natural attenuation processes in the soil and groundwater (Yong and Mulligan, 2019). However, the understanding of the fate and transport of the contaminants with the biosurfactants in the subsurface studies needs to be improved. Injection of genetically modified organisms in an in situ application will likely not be acceptable both to regulatory authorities and to the public.

\section{CONCLUSION}

In summary, biosurfactants have the potential for sustainable remediation of contaminated soils, sediments, and wastes (e.g., tannery and mining) due to their low toxicity, biodegradability, and effectiveness. However, the entire life cycle of the biosurfactant needs to be evaluated in order to optimize material, energy, and cost requirements. In situ production of the biosurfactants is potentially the most sustainable approach. Scale-up studies of the remediation process through partnership research and development are highly desirable.

\section{AUTHOR CONTRIBUTIONS}

The sole author CM prepared and edited the article completely with no assistance from anyone else.

\section{FUNDING}

Funding for the publication of this article was through the NSERC grant RGPIN-2016-05704.

\section{ACKNOWLEDGMENTS}

The author would like to acknowledge the contributions of all graduate students who assisted in the research over the years.

Amani, H. (2015). Study of enhanced oil recovery by rhamnolipids in a homogeneous 2D micromodel. J. Pet. Sci. Technol. 128, 212-219. doi: 10.1016/ j.petrol.2015.02.030

Ara, I., and Mulligan, C. N. (2015). Reduction of chromium in water and soil using a rhamnolipid biosurfactant. Geotech. Eng. J. SEAGS AGSSEA 46, 25-31.

Arab, F., and Mulligan, C. N. (2018). An eco-friendly method for heavy metal from mine tailings. Environ. Sci. Poll. Res. 25, 16202-16216. doi: 10.1007/s11356018-1770-3

Arab, F., and Mulligan, C. N. (2020). Removal of arsenic by sophorolipids from mine tailings. Environ. Geotech. 7, 175-188. doi: 10.1680/jenge.15.00016 
Așçi, Y., Nurbaş, M., and Açıkel, Y. S. (2008a). A comparative study for the sorption of Cd (II) by K-feldspar and sepiolite as soil components, and the recovery of Cd (II) using rhamnolipid biosurfactant. J. Environ. Manag. 88, 383-392. doi: 10.1016/j.jenvman.2007.03.006

Aşçi, Y., Nurbaş, M., and Açıkel, Y. S. (2008b). Removal of zinc ions from a soil component Na-feldspar by a rhamnolipid biosurfactant. Desalination 223, 361-365. doi: 10.1016/j.desal.2007.01.205

Ashish, M. D. (2018). Application of biosurfactant produced by an adaptive strain of C. tropicalis MTCC230 in microbial enhanced oil recovery (MEOR) and removal of motor oil from contaminated sand and water. J. Pet. Sci. Eng. 170, 40-48. doi: 10.1016/j.petrol.2018.06.034

Barajas-Aceves, M., Camarillo-Ravelo, D., and Rodriguez-Vasquez, R. (2015). Mobility and translocation of heavy metals from mine tailings in three plant species after amendment with compost and biosurfactant. Soil Sediment. Contam. Internat. J. 24, 224-249. doi: 10.1080/15320383.2015.94 6593

Bezza, F. A., and Chirwa, E. M. N. (2015). Production and applications of lipopeptide biosurfactants for bioremediation and oil recovery by Bacillus subtilis CN2. Biochem. Eng. J. 101, 168-187. doi: 10.1016/j.bej.2015.05.007

Cao, M., Hu, Y., Sun, Q., Wang, L., Chen, J., and Lu, X. (2013). Enhanced desorption of $\mathrm{PCB}$ and trace element metals $(\mathrm{Pb}$ and $\mathrm{Cu})$ from contaminated soils by saponin and EDSS mixed solution. Environ. Poll. 174, 93-99. doi: 10.1016/j.envpol.2012.11.015

Cazals, F., Huguenot, D., Crampon, M., Colombano, S., Betelu, S., Galopin, N., et al. (2020). Production of biosurfactant using the endemic bacterial community of a PAHs contaminated soil and its potential use for PAHs remobilization. Sci. Total Environ. 709:136143. doi: 10.1016/j.scitotenv.2019. 136143

Chen, W.-J., Hsiao, L.-C., and Chen, K. K. Y. (2008). Metal desorption from copper (II)/nickel(II)-spiked kaolin as a soil com- ponent using plant-derived saponic biosurfactant. Proc. Biochem. 43, 488-498. doi: 10.1016/j.procbio.2007. 11.017

Chen, W., Yan, Q., Xu, Z., He, F., Chen, Z., Huang, S., et al. (2017). Heavy metal $(\mathrm{Cu}, \mathrm{Cd}, \mathrm{Pb}, \mathrm{Cr})$ washing from river sediment using biosurfactant rhamnolipid. Environ. Sci. Poll. Res. Int. 24, 16344-16350. doi: 10.1007/s11356-0179272-2

Choi, Y. J., Kim, Y.-J., and Nam, K. (2009). Enhancement of aerobic biodegradation in an oxygen-limiting environment using a saponin-based microbubble suspension. Environ. Poll. 157, 2197-2202. doi: 10.1016/j.envpol.2009.04.014

Congiu, E., and Ortega-Calvo, J. J. (2014). Role of desorption kinetics in the rhamnolipid-enhanced biodegradation of polycyclic aromatic hydrocarbons. Environ. Sci. Technol. 48, 10869-10877. doi: 10.1021/es5011253

Cooper, D. G., and Paddock, D. A. (1984). Production of a biosurfactant from Torulopsis bombicola. Appl. Environ. Microbiol. 47, 173-176. doi: 10.1128/ AEM.47.1.173-176.1984

Da Rocha, R. B. Jr., Meira, H. M., Almeida, D. G., Rufino, R. Q., Luna, J. M., Santos, V. A., et al. (2019). Application of a low-cost biosurfactant in heavy metal remediation process. Biodegradation 30, 215-233. doi: 10.1007/s10532018-9833-1

Da Rosa, C. F. C., Freire, D. M. G., and Ferraz, H. C. (2015). Biosurfactant microfoam: application in the removal of pollutants from soil. J. Environ. Chem. Eng. 3, 89-94. doi: 10.1016/j.jece.2014.12.008

Das, A. J., and Kumar, R. (2018). Bioslurry phase remediation of petroleumcontaminated soil using potato peels powder through biosurfactant producing Bacillus licheniformis J1. Int. J. Environ. Sci. Technol. 15, 525-532. doi: 10.1007/ s13762-017-1410-3

Descaro, A., Machado, T. S., Cappaellaro, A. C., Reinehr, C. O., Thome, A., and Colla, L. M. (2017). Biosurfactants during in situ bioremediation: factors that influence the production and challenges in evaluation. Environ. Sci. Pollut. Res. 24, 20831-20843. doi: 10.1007/s11356-017-9778-7

Fanaei, F., Moussavi, G., and Shekoohiyan, S. (2020). Enhanced treatment of the oil-contaminanted soil using biosurfactant-assisted washing operation combined with $\mathrm{H}_{2} \mathrm{O}_{2}$-stimulated biotreatment of the effluent. J. Environ. Manag. 271:110941. doi: 10.1016/j.jenvman.2020.110941

Felix, A. K. N., Martins, J. J. L., Almeida, J. G. L., Giro, M. E. A., Calvacante, K. F., Melo, V. M. M., et al. (2019). Purification and characterization of a biosurfactant produced by Bacillus subtilis in cashew apple juice and its application in the remediation of contaminated soil. Colloids Surf. B Biointerfaces 175, 256-263. doi: 10.1016/j.colsurfb.2018.11.062

Gaur, A., Bajaj, A., Regar, R. K., Kamthan, M., Jha, R. R., Srivastava, J. K., et al. (2019). Rhamnolipid from a Lysininbacillus sphaericus IITR51 and its potential application for dissolution of hydrophobic pesticides. Biores. Technol. 272, 19-25. doi: 10.1016/j.biortech.2018.09.144

Gottfried, A., Singhai, N., Elliot, R., and Swift, S. (2010). The role of salicylate and biosurfactant in inducing phenanthrene degradation in batch soil slurries. Appl. Microbiol. Biotechnol. 86, 1563-1571. doi: 10.1007/s00253-0102453-2

Gusiatin, Z. M. (2014). Tannic acid and saponin for removing arsenic from brownfield soils: mobilization, distribution and speciation. J. Environ. Sci. 26, 855-864. doi: 10.1016/S1001-0742(13)60534-3

Hallmann, E., and Medrzycka, K. (2015). Wetting properties of biosurfactant (rhamnolipid) with synthetic surfactants mixtures in the context of soil remediation. Ann. UMCS 70, 29-39. doi: 10.1515/umcschem-20150003

Hentati, D., Cheffi, M., Hadrich, F., Makhloufi, N., Rabanal, F., Manresa, A., et al. (2021). Investigation of halotolerant marine Staphylococcus sp. CO100 as a promising hydrocarbon-degrading and biosurfactant-producing bacterium under saline conditions. J. Environ. Manag. 277:111480. doi: 10.1016/j. jenvman.2020.111480

Herman, D. C., Artiola, J. F., and Miller, R. M. (1995). Removal of cadmium, lead and zinc from soil by a rhamnolipid biosurfactant. Environ. Sci. Technol. 29, 2280-2285. doi: 10.1021/es00009a019

Hong, K. J., Tokunaga, S., and Kajiuchi, T. (2002). Evaluation of remediation process with plant-derived biosurfactant for recovery of heavy metals from contaminated soils. Chemosphere 49, 379-387. doi: 10.1016/S0045-6535(02) 00321-1

Jalali, F., and Mulligan, C. N. (2008). Enhanced Bioremediation of an oil and Heavy Metal Contaminated Soil by Stimulation of Biosurfactant Production, Geoenvironmental Engineering. 2008, Kyoto, June 12-14, 2008.

Jennings, E. M., and Tanner, R. S. (2000). "Biosurfactant-producing bacteria found in contaminated and uncontaminated soils," in Proceedings of the 2000 Conference on Hazardous Waste Research; 2000. Denver, CO, 299-306.

Jorfi, S., Rezaee, A., Jaafarzadeh, N. A., Esrafili, A., Akbari, H., and Ali, G. A. M. (2014). Bioremediation of pyrene-contaminated soils using biosurfactant. Jentashapir. J. Health Res. 5:e23228. doi: 10.17795/jjhr23228

Juwarkar, A. A., Nair, A., Dubey, K. V., Singh, S. K., and Devotta, S. (2007). Biosurfactant technology for remediation of cadmium and lead contaminated soils. Chemosphere 68, 1996-2002. doi: 10.1016/j.chemosphere.2007. 02.027

Kakinuma, A., Oachida, A., Shima, T., Sugino, H., Isano, M., Tamura, G., et al. (1969). Confirmation of the structure of surfactin by mass spectrometry. Agric. Biol. Chem. 33, 1669-1672. doi: 10.1080/00021369.1969.108 59524

Kilic, E., Font, J., Puig, R., Çolak, S., and Çelik, D. (2011). Chromium removal from heavy sludge with saponin and oxidative remediation. J. Hazard. Mater. 185, 456-462. doi: 10.1016/j.jhazmat.2010.09.054

Kim, J., and Vipulanandan, C. (2006). Removal of lead from contaminated water and clay soil using a biosurfactant. J. Environ. Eng. 132, 777-786. doi: 10.1061/ (ASCE)0733-9372(2006)132:7(777)

Kobayashi, T., Kaminaga, H., Navarro, R. R., and Iimura, Y. (2012). Application of aqueous saponin on the remediation of polycyclic aromatic hydrocarbonscontaminated soil. J. Environ. Sci. Health Part A 47, 1138-1145. doi: 10.1080/ 10934529.2012.668106

Lima de Franca, I. W., Lima, A. P., Lemos, J. A. M., Lemos, C. G. F., Melo, V. M. M., de Sant'ana, H. B., et al. (2015). Production of a biosurfactant by Bacillus subtilis ICA 56 aiming bioremediation of impacted soils. Cata. Today 255, 10-15. doi: 10.1016/j.cattod.2015. 01.046

Liu, G., Zhong, H., Yang, X., Liu, Y., Shao, B., and Liu, Z. (2018). Advances in applications of rhamnolipids biosurfactant in environmental remediation: a review. Biotechnol. Bioeng. 115, 796-814. doi: 10.1002/bit.26517 
Liu, Z., Li, Z., Zhong, H., Zeng, G., Liang, Y., Chen, M., et al. (2017). Recent advances in the environmental applications of biosurfactant saponins. A Rev. J. Environ. Chem. Eng. 5, 6030-6038. doi: 10.1016/j.jece.2017.11.021

Maity, J. P., Huang, Y. M., Hsu, C. M., Wu, C. I., Chen, C. C., Li, C. Y., et al. (2013). Removal of $\mathrm{Cu}, \mathrm{Pb}$, and $\mathrm{Zn}$ by foam fractionation and a soil washing process from contaminated industrial soils using soap-berry- derived saponin: a comparative effectiveness assessment. Chemosphere 92, 1286-1293. doi: 10. 1016/j.chemosphere.2013.04.060

Marchant, R. (2019). "The future of microbial biosurfactants and their applications," in Microbial Biosurfactants and their Environmental and Industrial Applications, eds I. M. Banat and R. Thavasi (, (Boca Raton, FL: CRC Press), 364-370. doi: 10.1201/b21950-14

Massara, H., Mulligan, C. N., and Hadjinicolaou, J. (2007). Effect of rhamnolipids on chromium contaminated soil. Soil Sediment. Contam. Internat. J. 16, 1-14. doi: 10.1080/15320380601071241

Mulligan, C. N. (2014b). "Enhancement of remediation technologies with biosurfactants. biosurfactant: future trends and challenges," in Biosurfactants Research and Application, eds C. N. Mulligan, S. K. Sharma, and A. Mudhoo (Boca Raton, FL: CRC Press), 231-276. doi: 10.1201/b1 6383

Mulligan, C. N. (2014a). "Characterization, production, and applications of lipopeptides," in Biosurfactants: Research Trends and Applications, eds C. N. Mulligan, S. K. Sharma, and A. Mudhoo (Boca Raton, FL: CRC Press), 147-176. doi: 10.1201/b16383

Mulligan, C. N., and Gibbs, B. F. (1993). "Factors influencing the economics of biosurfactants," in Biosurfactants, Production, Properties, Applications, ed. N. Kosaric (New York, NY: Marcel Dekker), 329-371.

Mulligan, C. N., Oghenekevwe, C., Fukue, M., and Shimizu, Y. (2007). "Biosurfactant enhanced remediation of a mixed contaminated soil and metal contaminated sediment," in Proceedings of the Seventh Geoenvironmental Engineering Seminar, Japan-Korea-France, Grenoble, France, May 19-24, 2007. Grenoble.

Mulligan, C. N., Yong, R. N., and Gibbs, B. F. (1999b). On the use of bio- surfactants for the removal of heavy metals from oil-contaminated soil. Environ. Prog. 18, 50-54. doi: 10.1002/ep.670180120

Mulligan, C. N., Yong, R. N., and Gibbs, B. F. (1999a). Metal removal from contaminated soil and sediments by the biosurfactant surfactin. Environ. Sci. Technol. 33, 3812-3820. doi: 10.1021/es9813055

Mulligan, C. N., Yong, R. N., and Gibbs, B. F. (2001). Heavy metal removal from sediments by biosurfactants. J. Hazard. Mat. 85, 111-125. doi: 10.1016/S03043894(01)00224-2

Mulligan, C. N., and Wang, S. (2004). "Remediation of a heavy metal contaminated soil by a rhamnolipid foam," in Proceedings of the Fourth BGA Geoenvironmental Engineering Conference, Stratford-Upon-Avon, U.K., June 2004. Stratford-Upon-Avon. doi: 10.1680/geimogacl.32774. 0065

Mulligan, C. N. (2019). Sustainable Engineering, Principles and Implementation. Boca Raton, FL: CRC Press. doi: 10.1201/9780429027468

Mulligan, C. N., and Roshtkhari, S. (2016). Application of microbial microbial culture and rhamnolipid for improving sedimentation of oil sand tailings. J. Biorem. Biodegrad. 7:1000358. doi: 10.4172/2155-6199.1000358

Nikolopoulaou, M., Pasadakis, N., Norf, H., and Kalogerakis, N. (2013). Enhanced es sit bioremediation of crude oil contaminated beach sand by supplementation with nutrients and rhamnolipids. Mar. Poll. Bull. 77, 37-44. doi: 10.1016/j. marpolbul.2013.10.038

Ochoa-Loza, F. (1998). "Physico-Chemical Factors Affecting Rhamnolipid Biosurfactant Application for Removal of Metal Contaminants from Soil," in Ph.D dissertation, University of Arizona, Tucson, AR.

Qian, G., Jia, Y., Wen, J., Hu, Y., Chen, Y., and Wu, W. (2016). Rhamnolipid enhanced aerobic biodegradation of triclosan (TCS) by indigenous microorganisms in water-sediment systems. Sci. Total Environ. 571, 1304-1311. doi: 10.1016/j.scitotenv.2016.07.171

Resende, A. H. M., Da Rocha e Silva, N. M. P., Rufin, R. D., de Luna, J. M., and Sarubbo, L. A. (2017). Biosurfactant production by bacteria isolated from seawater for remediation of environments contaminated with oil products. Chem. Eng. Transact. 57, 1555-1560.

Rufino, R. D., Luna, J. M., Marinho, P. H. C., Farias, C. B. B., Ferreira, S. R. M., and Sarubbo, L. A. (2013). Removal of petroleum derivative adsorbed to soil by biosurfactant Rufisan produced by Candida lipolytica. J. Pet. Sci. Eng. 109, 117-122. doi: 10.1016/j.petrol.2013.08.014

Saborimanesh, N., and Mulligan, C. N. (2018). Dispersion of weathered biodiesel, diesel and light crude oil in the presence of sophorolipid biosurfactant in seawater. J. Environ. Eng. 144:04018028. doi: 10.1061/(ASCE)EE.1943-7870. 0001369

Saborimanesh, N., and Mulligan, C. N. (2015). Effect of sophorolipid biosurfactant on oil biodegradation by the natural oil-degrading bacteria on the weathered biodiesel, diesel and light crude oil. J. Biorem. Biodegrad. 6:1000314. doi: 10.4172/2155-6199.1000314

Sharma, D., Ansari, M. J., Al-Ghamdi, A., Adgada, N., Khan, K. A., Pruthi, V., et al. (2015). Biosurfactant production by DSVP20 isolated from petroleum hydrocarbon-contaminated soil and its physicochemical characterization. Environ. Sci. Poll. Res. 22, 1-8. doi: 10.1007/s11356-0154937-1

Singh, A. K., and Cameotra, S. S. (2013). Efficiency of lipopeptide bio- surfactants in removal of petroleum hydrocarbons and heavy metals from contaminated soil. Environ. Sci. Poll. Res. 20, 7367-7376. doi: 10.1007/s11356-0131752-4

Singh, P., Saini, H. S., and Raj, M. (2016). Rhamnolipid mediated enhanced degradation of clorpyrifos by bacterial consortium in soil-water system. Ecotox. Env. Saf. 134, 156-162. doi: 10.1016/j.ecoenv.2016.07.020

Song, S., Zhu, L., and Zhou, W. (2008). Simultaneous removal of phenanthrene and cadmium from contaminated soils by saponin, a plant-derived biosurfactant. Environ. Poll. 156, 1368-1370. doi: 10.1016/j.envpol.2008. 06.018

Slizovsky, I. B., Klsey, J. W., and Hatzinger, P. B. (2011). Surfactantfacilitated remediation of metal-contaminated soils: efficacy and toxicological consequences to earthworms. Environ. Toxicol. Chem. 30, 112-123. doi: 10. 1002/etc.357

Suryanti, V., Hastuti, S., and Andriani, D. (2016). Optimization of biosurfactant production in soybean oil by Rhodococcus rhodochrous and its utilization in remediation of cadmium-contaminated solution. IOP Conf. Ser. Mater. Sci. Eng. 107:012018. doi: 10.1088/1757-899X/107/1/012018

Taira, T., Yanagisawa, S., Nagano, T., Zhu, Y., Kuroiwa, T., Koumara, N., et al. (2015). Selective encapsulation of cesium ions using the cyclic peptide moiety of surfactin: highly efficient removal based on an aqueous giant micellar system. Colloids Surf. B Biointerfaces 134, 59-64. doi: 10.1016/j.colsurfb.2015.06.034

Tan, H., Champion, J. T., Artiola, J. F., Brusseau, M. L., and Miller, R. M. (1994). Complexation of cadmium by a rhamnolipid biosurfactant. Environ. Sci. Technol. 28, 2402-2406. doi: 10.1021/es00062a027

Thimon, L., Peyoux, F., Maget-Dana, R., and Michel, G. (1992). Surface-active properties of antifungal lipopeptides produced by Bacillus subtilis. JAOCS 69, 92-93. doi: 10.1007/BF02635884

Wang, S., and Mulligan, C. N. (2009b). Rhamnolipid biosurfactant- enhanced soil flushing for the removal of arsenic and heavy metals from mine tailings. Proc. Biochem. 44, 296-301. doi: 10.1016/j.procbio.2008.11.006

Wang, S., and Mulligan, C. N. (2009a). Arsenic mobilization from mine tailings in the presence of a biosurfactant. Appl. Geochem. 24, 928-935. doi: 10.1016/j. apgeochem.2009.02.017

Wan, J., Meng, D., Long, T., Ying, R., Ye, M., Zhang, S., et al. (2015). Simultaneous removal of lindane, lead and cadmium from soils by rhamnolipids combined with citric acid. PLoS One 10:e00129978. doi: 10.1371/journal.pone.0129978

Wang, C. P., Li, J., Jiang, Y., and Zhang, Z. Y. (2014). Enhanced bioremediation of field agricultural soils contaminated with PAHs and OCPs. Int. J. Environ. Res. 8, 1271-1278.

Whang, L. M., Liu, P. W., Ma, C. C., and Cheng, S. (2008). Application of biosurfactants, rhamnolipid and surfactin for enhanced biodegradation of diesel-contaminated water and soil. J. Hazard. Mat. 151, 155-163. doi: 10.1016/ j.jhazmat.2007.05.063

Ye, M., Sun, M., Wan, J., Fang, G., Li, H., Hu, F., et al. (2015). Evaluation of enhanced soil washing process with tea saponin in a peanut oil/water solvent system for the extraction of PBDEs/PCBs/PAHs and heavy metals from an electronic waste site followed by vetiver grass phytoremediation. J. Chem. Technol. Biotechnol. 90, 2027-2035. doi: 10.1002/jctb.4512

Yong, R. N., and Mulligan, C. N. (2019). Natural and Enhanced Attenuation of Contaminants in Soils, 2nd Edn. Boca Raton, FL: CRC Press. doi: 10.1201/ 9781315159195 
Yong, R. N., Mulligan, C. N., and Fukue, M. (2014). Sustainable Practices in Geoenvironmental Engineering, 2nd Edn. Boca Raton, FL: CRC Press. doi: 10. 1201/b17443

Zeng, G. M., Zhong, H., Huang, G. H., and Fu, H. Y. (2005). Physicochemical and microbiological effects of biosurfactant on the remediation of HOCcontaminated soil. Prog. Nat. Sci. Mater. Int. 15, 577-585. doi: 10.1080/ 10020070512331342590

Zhang, J., Li, J., Chen, L., and Thring, R. W. (2011). "Remediation of refinery oily sludge using isolated strain and biosurfactant," in Proceedings of the Water Resource and Environmental Protection (ISWREP), 2011 International Symposium, Xian, China, May 20-22, 2011. Xian, Vol. 3, 1649-1653.

Zhou, W., Wang, X., Chen, C., and Zhu, L. (2013). Enhanced soil washing of phenanthrene by a plant-derived natural biosurfactant, Sapindus saponin. Colloid Surface A 425, 122-128. doi: 10.1016/j.colsurfa.2013. 02.055

Conflict of Interest: The author declares that the research was conducted in the absence of any commercial or financial relationships that could be construed as a potential conflict of interest.

Copyright (c) 2021 Mulligan. This is an open-access article distributed under the terms of the Creative Commons Attribution License (CC BY). The use, distribution or reproduction in other forums is permitted, provided the original author(s) and the copyright owner(s) are credited and that the original publication in this journal is cited, in accordance with accepted academic practice. No use, distribution or reproduction is permitted which does not comply with these terms. 